\title{
Demand for higher education programs: the impact of the Bologna process*
}

\author{
Ana Rute Cardoso \\ IZA Bonn ${ }^{\dagger}$ \\ Miguel Portela \\ Tinbergen Institute, NIPE-University of Minho, and IZA Bonn \\ Carla Sá \\ NIPE-University of Minho \\ Fernando Alexandre \\ NIPE-University of Minho
}

March 2007

\begin{abstract}
The Bologna process aims at creating a European Higher Education Area where inter-country mobility of students and staff, as well as workers holding a degree, is facilitated. While several aspects of the process deserve wide public support, the reduction of the length of the first cycle of studies to three years, in several continental European countries where it used to last for four or five years, is less consensual. The paper checks the extent of public confidence in the restructuring of higher education currently underway, by looking at its implications on the demand for academic programs in Portugal. Precise quantification of the demand for each academic program is facilitated by the rules of access to higher education, in a nation-wide competition, where candidates must list up to six preferences of institution and program. We use regression analysis applied to count data, estimating negative binomial models. Results indicate that the programs that restructured to follow the Bologna principles were subject to higher demand than comparable programs that did not restructure, as if Bologna were understood as a quality stamp. This positive impact was reinforced if the institution was a leader, i.e. the single one in the country that restructured that program. Still an additional increase in demand was experienced by large programs that restructured to offer an integrated master degree, thus conforming to Bologna principles while not reducing the program duration.
\end{abstract}

KEYWORDS: education policy; European Higher Education Area; economic, social and cultural integration; count data.

JEL CODES: I28, I21, F15.

\footnotetext{
*We are grateful to Paulo Guimarães, Dan Hamermesh, and Pedro Portugal for their comments on an earlier version of the paper, and to Nelson Areal for constructive interaction.

${ }^{\dagger}$ Corresponding author: Ana Rute Cardoso, IZA, Schaumburg-Lippe-Str. 7/9, 53113 Bonn, Germany. E-mail: cardoso@iza.org
} 


\section{Introduction}

The Bologna process is a far-reaching reform, involving currently 45 countries, which aims at the creation of a European Higher Education Area by 2010. Major steps in that direction, currently underway, include the creation of a comparable structure of academic degrees, mutual recognition of diplomas and course units, the assessment of academic institutions and programs based on common quality standards, and direct incentives to geographical mobility of students and staff. Implementation of a common structure of academic degrees means that some continental European countries are having to move from a four- or five-year first cycle of studies into a shorter three-year one, which led to controversy. On the one hand, the advantages of having a degree recognized in a wider geographical space are praised, together with the redevelopment of curricula that makes learning more student-centered and focused on the development of competencies, while enabling earlier entrance into the labor market. On the other hand, distrust has been expressed over the academic contents and adequacy to labor market needs of the competencies transmitted in a shorter three-year period, with fears that the employability of graduates will be reduced, when compared to graduates of the longer cycle.

This study aims at checking the degree of public confidence in the restructuring of the first cycle of higher education studies currently taking place under the Bologna process. More precisely, we concentrate on the reaction of students, to analyze the impact of the Bologna restructuring on demand for academic programs by candidates to higher education. We focus on the Portuguese system.

We take advantage, first of all, of the legal setting in Portugal, where institutions were given the option to adjust their academic programs to the Bologna curricula starting in the academic year 2006/07, or to defer adjustment to one of the two following years. Therefore, in 2006/07 a group of early implementers coexists with a group of academic programs that still have not undergone change, and students were free to choose where they would like to be admitted. Under this setting, the decisions by academic institutions and students can be analyzed in the conventional signaling framework (Gibbons, 1992; Salanié, 2000). Academic institutions decide whether to adopt immediately the Bologna principles and students decide whether to apply to a Bologna program. Institutions are in this case the informed players, who have insider 
information on program quality, which they can choose to reveal (or not) by means of signals. Interestingly, in the public debate surrounding the Bologna changes, the idea that institutions that adapted first were signaling their readiness for change and their higher quality, was often stressed. Prospective students, on the other hand, are free to apply to a particular institution and they are presumably interested in attending an institution that guarantees a certain education quality (Long, 2004). Whereas the program quality is institution's private information, the decision to conform to the Bologna principles is publicly observed. Under this framework, our main purpose is to test whether students sort out academic programs by looking at whether the curriculum has been adapted to Bologna.

Secondly, the analysis is facilitated by the system of access to higher education in Portugal. Candidates must clearly rank up to six choices of institution and academic program, and a national competition follows, run by the Ministry of Science, Technology and Higher Education (MSTHE), which allocates candidates based on their relative performance and the number of available vacancies posted by each institution for each program. Thirdly, we have a comprehensive dataset on the application process, which renders this analysis feasible.

The paper proceeds describing the main characteristics of the Bologna process in the international context, in section 2.1. Sections 2.2 and 2.3 concentrate on Portugal, to present the higher education system and describe the implementation of the Bologna process, showing how it provides good conditions for economic analysis under the basic signaling framework. The empirical strategy is presented in the following sections: section 3.1 presents the data set and section 3.2 describes the method and major problems to be tackled. Section 4 discusses the results, before concluding comments are presented.

\section{Implementation of the Bologna process}

\section{$2.1 \quad$ International context}

The 1960s and 1970s witnessed in Europe an expansion of the higher education system. Since then, the number of students has increased rapidly and new types of higher education programs have been created (e.g., professional higher education). Meanwhile, an increasing number of students decided to go abroad for at least part of their higher 
education. With rising international mobility of students, European countries started considering the coordination of their higher education systems. At the same time, globalization and increased international competition highlighted the importance of making European higher education institutions attractive to the world. Initial steps towards the coordination of European higher education systems were taken with the signature of the Sorbonne declaration by the Ministers in charge of higher education of France, Italy, United Kingdom and Germany, in 1998, and later, in 1999, with the signature of the Bologna declaration. These steps were followed by Ministerial Conferences at Prague 2001, Berlin 2003, and Bergen 2005.

The Bologna process aims at creating a European Higher Education Area, where internal mobility of students, teachers, and administrative staff is facilitated, whose competitiveness attracts students from outside and contributes to the broader aim of turning Europe into a leading knowledge-based society. For a discussion of the benefits of degree standardization and harmonization and of international mobility, in creating competitive European higher education institutions see, among others, van der Ploeg and Veugelers (2007). The main pillars of the process include:

- Comparability of the degree structure, based on three cycles: the bachelor degree (three years, according to the dominant model), the master (normally two years), and the doctorate.

- Mutual recognition of degrees, other awards, and course units. Further to a comparable degree structure, a system of academic credits was created, whose accumulation and transferability across countries is guaranteed, enabling mutual recognition of degrees, other academic qualifications, and periods of study abroad. In the same line, a Diploma Supplement was introduced, which describes the degree and qualifications obtained, in terms of workload, level, and learning outcomes. The overall aim is to improve transparency of higher education degrees and to render more flexible progression into further studies and access to the labor market, while improving the attractiveness of the European higher education system.

- Assessment and accreditation of institutions and academic programs based on shared quality standards and procedures.

- Development of mobility programs by student, teaching, research and administrative staff, including measures such as the portability of national loans and grants. 
- External dimension of the process, through exchange and cooperation with other parts of the world (for example, Latin American and the Caribbean).

Even though the process is far-reaching and multifaceted, much attention has been devoted to the changes in the degree structure. Indeed, according to the model that predominated in several continental European countries, the first higher education degree was obtained after four to five years of successful study. Therefore, the curricula changes necessary to bring the first degree down to three-years are being implemented amidst some controversy.

On one hand, the advantages of having a comparable degree structure are stressed, as the system becomes more transparent and obstacles to the mobility of students and workers are reduced. However, the new curricula are often interpreted as a compressed version of the longer programs, and critics claim that there will not be enough time for assimilation, reflection and a critical approach to learning, which will undermine the quality of the degree. Under these circumstances, the employability of the new graduates might be reduced, when competing with graduates from the previous system of a longer first cycle. Moreover, there is the fear that public funding will be restricted to the first (three-year) cycle, thus imposing a higher burden on students if they want to progress beyond the first degree, when compared to the system that used to guarantee public funding for four or five years.

The relevance attached to this issue varies across scientific fields, with the problem usually not raised in the humanities, while it is highlighted in several countries for occupations regulated by professional bodies (Reichert and Tauch, 2005) and subject to specific European Union coordination mechanisms (see the case of architecture and health sciences).

Between optimism and skepticism, it is not certain how the behavior of students and labor market agents will change during the period of adjustment to the Bologna changes in higher education curricula.

\subsection{Portuguese higher education system: organization and admission pro- cedures}

Portugal has a binary higher education system comprising universities and polytechnic schools. ${ }^{1}$ The former aim at providing general academic education and they are in

\footnotetext{
${ }^{1}$ As well as the military and police institutions, and the Open University (institution for distance learning).
} 
charge of most research activity, whereas the latter are traditionally more vocationally oriented. This study concentrates on the publicly funded higher education system, which comprises 14 universities and 26 polytechnics. ${ }^{2}$

Most higher education institutions are located in the densely populated coastal area. The capital, Lisbon, harbors four universities; among the remaining universities, three are located in the north (Braga/Guimarães, Oporto and Vila Real), three in the center (Aveiro, Coimbra and Covilhã), two in the south (Évora, Faro) and two in the islands (Azores and Madeira). Polytechnics are the result of a policy of local development promotion. Though more evenly spread over the country, there is still some concentration by the coastal line.

Enrollment in higher education is limited by a system of numerus clausus. The number of vacancies is defined yearly by each institution, subject to communication to the MSTHE. ${ }^{3}$ The application process takes place at the centralized national level. Each candidate ranks up to six priorities, each comprising a pair institution/program. The nation-wide competition that follows allocates the candidates based on their grade point average and the stated ranking of preferences.

Successful completion of secondary education is a prerequisite for admission into higher education by students younger than 23 years. ${ }^{4}$ In addition, candidates must pass national admission exams. Definition of the number of exams, their subjects, the minimum classification required, the weighting scheme to compute the final grade point average, and the minimum grade point average required, rests with each institution. ${ }^{5}$ In any case, the number of exams required must be one or two, and the computation of the final grade point average (expressed in a scale of 0 to 200) for ranking the applicants to each institution and program must obey the following rules: the grade point average at completion of secondary school, which takes into consideration the three final years of secondary school, must have a weight of at least 50 percent; the specific national

\footnotetext{
${ }^{2}$ The private system comprises 55 universities and 60 polytechnics, but most of these institutions are of small dimension, offering a very restricted number of study programs, in one or two areas. This sub-system is not subject to analysis here, first of all because private providers have more freedom to define the application and admission rules (for example, the timing for applications is very different, with several private institutions defining the application phase such that students can still apply after they know the results from the public sector contest). Secondly, there is no centralized application procedure in the private sector, thus making it very difficult to collect enough and comparable data for analysis.

${ }^{3}$ Who can, under special circumstances, change the proposal. For a few programs, joint approval by this Ministry and a second one is required.

${ }^{4} 25$ years old, until 2005 . Older candidates who do not hold a secondary school degree are subject to a different set of exams specific to each program.

${ }^{5}$ In special cases where physical, vocational or other abilities are relevant, other specific admission requirements may apply (pré-requisitos).
} 
admission exam(s) must have a weight of at least 35 percent. ${ }^{6}$

Certain admission exams are known to place tougher requirements on the applicants. Traditionally hard subjects are: mathematics, where only $26 \%$ of the students obtained in 2006 a passing grade (27\% in 2005, and $31 \%$ in 2004 and 2003); physics, where the share of students passing the exam was $30 \%, 47 \%, 37 \%$, and $22 \%$, respectively in 2006 , 2005, 2004, and 2003; and chemistry, where those shares were, respectively, 35\%, 52\%, $41 \%$ and $53 \%$.

The allocation of candidates comprises two major phases: the first one takes place in July/August; the second takes place in August/September and includes the vacancies that have not been filled in the first phase. Students who were not successful in the first phase, or who were successful but wish to change the institution/program where they were placed, and those who had not applied in the first phase (either because they did not yet fulfill all the requirements or because, though fulfilling the requirements, had decided not to apply), are eligible to apply in the second phase.

\subsection{The Bologna process in Portugal: a signaling framework}

The implementation of the Bologna process, led by the Portuguese MSTHE, is part of a process of reorganization and rationalization of the higher education system (OECD, 2006), taking place in a framework of growing imbalances between demand and supply. In fact, the number of students enrolled in higher education doubled during the 1990s, with enrollment in public universities increasing by $62 \%$ (MSTHE, 2006) and the remaining being absorbed through expansion of public polytechnics and the private sector. However, since then a number of factors have combined to generate excess of capacity and increasing competition for students between institutions. Among these factors, the MSTHE (2006) stresses: the decline in the number of candidates, due to demographic changes; the increasingly strict admission conditions, following the reintroduction of national admission exams and minimum grades; and the increased number of vacancies, due to large investments made in the public sector.

This increased competition motivated strategies of differentiation by institutions, namely by defining different entry conditions, with the most recognized institutions setting higher entrance standards and, therefore, targeting different segments of the student population (MSTHE, 2006). The speed of adjustment to the Bologna process

\footnotetext{
${ }^{6}$ If other special requirements apply, they cannot be attached a weight larger that 15 percent.
} 
has often been pointed out as an instrument in this strategy of differentiation. Like in other continental European countries, the reduction of the length of the first cycle of studies was one of the more debated Bologna changes. The common duration of a higher education degree used to be in Portugal five years, until mid-1990s, when it was reduced to four years; the Bologna process further imposes a reduction to three years. There is nevertheless the possibility to keep the duration of a program longer. Whereas the first cycle (licenciatura) has a normal duration of three years and the second cycle (mestrado) has a normal duration of one and a half or two years, in special cases it is feasible to offer a combined degree, the so-called integrated master, lasting for five to six years.

Institutions could choose to start implementing the Bologna curricula changes in the academic year of 2006/07 or one of the two following years. Some institutions saw the prompt implementation of the Bologna process as an opportunity to establish or reinforce a reputation of an up-to-date institution, whose graduates would benefit from the opportunities of a wider labor market. Institutions taking the lead might gain a comparative advantage over the late-comers, not just attracting more applicants in the first year after restructuring, but also gaining a reputation beneficial for future years. Other institutions, instead, opted to delay the process, arguing that changes should be thought over, and that the labor market would penalize the graduates from the new shorter first cycle. Table 5 shows that about $43 \%$ of the study programs have adjusted to the Bologna principles. Table 6 further disaggregates that number by institution. The decision by the University of Coimbra to defer to 2007/08 the adoption of the new model (with exceptions authorized for programs on which a national consensus for change had been reached among institutions) is evident in the table, as is the fact that University of Madeira did not adapt any of its programs. This decision contrasted to that of Universidade Nova de Lisboa and ISCTE, which moved ahead restructuring most of its programs.

Previous research has suggested that the demand for higher education programs depends on program quality and prestige (e.g., Long, 2004), which in turn reflects on individuals labor market performance (e.g., Black and Smith, 2004). However, as identified in the OECD's review of the Portuguese higher education system, "the level of public information on course content, program goals, quality and opportunities and graduate employment is inadequate or unavailable"(OECD, 2006: 27). For example, it 
was just in 2006 that a formal independent accreditation agency was announced, starting activity in 2007. The lack of independent institutions delivering publicly available quality assessments implies that students lack precise guidance in their choice processes.

In this context, the decision regarding adoption of the Bologna principles can be analyzed in the framework of the conventional signaling model, where students can infer the quality of the academic program by checking whether it has been reformulated to follow the Bologna principles. ${ }^{7}$ In the signaling process between institutions and students, the former is the informed player, having insider information on program quality. Even though quality is not synonymous with being in the leading group of Bologna adopters, in the public discussions it has often been highlighted that readiness for change towards international standards and fulfillment of stricter quality guidelines, provides an indication of academic quality. Moreover, the quality of the academic program and its ability to adapt to Bologna rules may be positively correlated, if both depend on the quality of the research activities developed in a department or even the readiness to work of its staff members. Having allowed institutions to choose the moment to implement the Bologna principles, the Portuguese higher education sector provides a good illustration of the strategic problem of institutions.

Students may themselves have opted for contrasting strategies. Some may associate Bologna with a quality stamp and a guarantee of recognition of the degree in a wider geographical space, yielding better employment opportunities, whereas others may attach a higher reputation to a more established longer program. The candidates to a higher education degree will be the agent we consider, and their demand for higher education programs the precise indicator under scrutiny. The aim is to check whether students read the Bologna signal as an indicator of program quality.

This analysis is rendered feasible by the fact that admission into higher education in Portugal is strictly regulated and implemented through a nation-wide competition, where candidates must clearly state their preferences for institutions and academic programs. Demand can thus be quantified in an unequivocal way.

\footnotetext{
${ }^{7}$ For an example of a signaling game applied to the higher education system, see Mizrahi and Mehrez (2002).
} 


\section{Empirical strategy}

\subsection{Data set}

The data used is made publicly available by the MSTHE, on a web site of the Department of Higher Education (DGES) dedicated to announce the results of the process of allocation of candidates to higher education programs. ${ }^{8}$

Data for the academic years 2003/2004 to 2006/2007 have been collected. The following variables are available: overall demand for each program (total number of students listing the pair institution/program among their preferences, irrespective of its ranking), as well as the number of students who have selected each program as their first choice, second choice and so forth (up to a maximum of six choices); number of vacancies available at each program in each of the two stages of the application process; national admission exams required by the program, with the major ones being mathematics, physics, chemistry, biology and portuguese; the field of study of the program. ${ }^{9}$

Table 5 in appendix provides descriptive statistics on the dataset. The second phase of application involves, as expected, remarkably less applicants, since it can be considered the residual phase. A declining trend in the number of applications can be detected between 2003 and 2005, with an increase in the number of applicants the following year. A declining proportion of programs required an entrance exam on maths, physics, chemistry, biology or portuguese. The share of applicants to each field of study has remained rather stable over time.

\subsection{Model under estimation}

Two alternative concepts are used to quantify the demand for each program at an institution:

- Hits: number of applicants who placed that program in that institution among their choices (irrespective of its ranking, from first to sixth).

- First choice: number of applicants who placed that institution and program as their first choice.

\footnotetext{
${ }^{8}$ Direcção Geral do Ensino Superior, at http://www.acessoensinosuperior.pt. Throughout the text, a program is meant to refer to a pair institution/academic program, unless otherwise explicitly explained.

${ }^{9}$ We have consistently used the classification adopted by the Ministry in 2006, which includes ten areas: agriculture, architecture, natural sciences, law and social sciences, economics and business, sports and arts, education, humanities, health, and technologies.
} 
The dependent variable in our model is thus a nonnegative integer. The distribution of the variable is in both cases skewed to the left. As such, an adequate tool to model the process is the count data regression analysis (Cameron and Trivedi, 1998).

Given the panel structure of the data, we started with the fixed effects Poisson model, to take into account unobserved heterogeneity across academic programs. The descriptive statistics reveal that the dependent variable presents raw overdispersion. This indicates that the negative binomial regression model might be more appropriate for our data, since it relaxes the hypothesis of equal mean and variance. The results of formal overdispersion tests indeed show clearly that a negative binomial specification is more appropriate. ${ }^{10}$

However, Allison and Waterman (2002) point out that the fixed-effects negative binomial model, as defined by Hausman et al. (1984), is not a fixed-effects model in the usual sense, because the fixed effect applies to the overdispersion parameter, rather than to the covariates. That is, that model specification solves the overdispersion problem, but does not guarantee that the program-specific effects are conditioned out of the likelihood. Guimarães further shows that in the parameterization proposed by Hausman et al. (1984) "the individual fixed effects will cancel out only if [...] there is a specific functional relation between the individual fixed effect and the individual overdispersion parameter" (Guimarães, 2006: 4), which is not necessarily true. As such, a test for the null hypothesis of successful removal of the fixed effects is required. To our knowledge, the only test available is that proposed by Guimarães (2006). When applied to our data, that test rejects the null hypothesis. Nevertheless, according to the simulations performed by Guimarães (2006), the test is not recommended for samples with small time dimensions, as is our case. ${ }^{11}$

Gathering all the arguments and evidence, we have decided to implement in the analysis that follows the strategy by Allison and Waterman (2002), which consists on estimation on the pooled sampled of an unconditional negative binomial model with dummy variables to account for the fixed effects. We report below the results of this

\footnotetext{
${ }^{10}$ The test is based on the idea that a fixed effects Poisson model can be seen as a multinomial model (see Guimarães and Lindrooth, 2005), implying that testing for overdispersion in the multinomial model can achieve testing for overdispersion in the Poisson model. We then use a Pearson test for the null hypothesis of no overdispersion in the multinomial model, which is rejected at any ordinary level of significance in all the specifications reported later. The overdispersion test was implemented using the Stata command MULTIN.

${ }^{11}$ According to Guimarães (2006: 7) "with panels as large as 1000 individuals the test requires at least 20 observations per individual to adequately control for type I error."
} 
model. ${ }^{12}$ Following Cameron and Trivedi (1998), the model is specified as

$$
\operatorname{Pr}(Y=y \mid \mu, \alpha)=\frac{\Gamma\left(y+\alpha^{-1}\right)}{\Gamma(y+1) \Gamma\left(\alpha^{-1}\right)}\left(\frac{\alpha^{-1}}{\alpha^{-1}+\mu}\right)^{\alpha^{-1}}\left(\frac{\mu}{\alpha^{-1}+\mu}\right)^{y}
$$

where $y$ is the count for our dependent variable, $\mu=\exp (\mathbf{x} \beta), \alpha \geq 0$ is the overdispersion parameter, $\Gamma($.$) is the gamma function, and \mathbf{x}$ is a vector of regressors, including a dummy variable for each study program. This specification assumes constant dispersion within groups, equal to $1+\alpha \mu$. The mean and variance of $y$ are defined as $\mu$ and $\mu+\alpha \mu^{2}$, respectively.

The vector of regressors $\mathbf{x}$, the program attributes, includes, first of all, whether it requires a national admission exam in a particular subject (dummy variables for mathematics, physics, chemistry, biology and portuguese). Controlling for the subjects required as admission exams is particularly relevant. Indeed, a generally poor performance in the admission exam in a certain subject reduces the size of the population that can potentially apply to programs requiring that exam. Secondly, we controlled for the scientific field of the program (captured by 9 dummy variables). Different scientific fields reacted differently to the implementation of the Bologna process (consider for example the contrast between humanities and other fields). Estimation of the model including field-specific dummy variables can control for these differences. We also control for the phase of the application process, with a dummy variable equal to one in the second phase, since this is a residual phase, for vacancies not previously filled and students who were not placed in the first phase or who wish to be placed elsewhere. Given sharp differences in the dimension of the different programs and across institutions, we also control for the size of the program (number of vacancies posted). The crucial variable, Bologna06, achieves the value one if the program was restructured to adapt to the Bologna principles, and zero otherwise.

All the specifications include a fixed effect for each program. The model thus accounts for endogenous adoption of the new academic model. In fact, the timing and extent of adaptation to the Bologna principles may be viewed as a political decision by the direction of the program at each institution, which may self-select into restructuring promptly or delaying adjustment, based on, among other factors, expectations about demand for their programs. These program-specific effects capture as well fac-

\footnotetext{
${ }^{12}$ The results are similar to those obtained with the fixed-effects Poisson or negative binomial models. All sets of results are available from the authors upon request.
} 
tors other than its strategy, such as the amount of resources, reputation, or regional conditions.

Three variables were used to capture the group of Bologna adopters:

- Bologna implementer: a program at an institution, which has been restructured according to the Bologna process.

- Bologna leader: a Bologna implementer, who was the only institution in the country that restructured that academic program. This group of early-implementers has set itself apart from the other institutions in the country, making an early move and most likely expecting to gain from its timing. It is a group more likely to be affected (either gaining or losing) by the change.

- Bologna implementer without shortening the duration of the program (integrated master): the possibility used by some institutions to restructure a program while nevertheless keeping a duration longer than the normal Bologna duration for the first cycle is explicitly taken into account. We distinguish between programs that reduced their duration and those that, though having restructured to conform to the Bologna principles, offer a joint first and second cycle degree, thus keeping a longer duration.

Comparison of the first and last specifications allows in particular to check the relevance attached by candidates to the stamp and reputation associated with Bologna, and to the change in the duration of the program.

\section{Impact of the Bologna process}

This section presents results of the estimation of the negative binomial model just described. Alternative specifications of the model are reported, using in every case the variable hits to quantify the demand for a program, i.e. the total number of candidates that listed the program among their preferences, irrespective of its rank position. The first specification controls for the phase in the application process, program size, the set of admission exams required, field of study and a time trend. Specification 2 further allows the time trend to diverge across fields of study. Specification 3 further checks whether the impact of the Bologna process was different across fields of study. 
Table 1: Demand for academic programs (total number of students choosing the program), negative binomial model

\begin{tabular}{|c|c|c|c|}
\hline Variable & Spec. 1 & Spec. 2 & Spec. 3 \\
\hline Phase 2 & $\begin{array}{c}-0.905^{* * *} \\
(0.023)\end{array}$ & $\begin{array}{c}-0.902^{* * *} \\
(0.024)\end{array}$ & $\begin{array}{c}-0.902^{* * *} \\
(0.024)\end{array}$ \\
\hline Size of program (vacancies) & $\begin{array}{c}0.005^{* * *} \\
(0.0007)\end{array}$ & $\begin{array}{c}0.005^{* * *} \\
(0.0007)\end{array}$ & $\begin{array}{c}0.005^{* * *} \\
(0.0007)\end{array}$ \\
\hline Bologna06 & $\begin{array}{c}0.191^{* * *} \\
(0.043)\end{array}$ & $\begin{array}{c}0.195^{* * *} \\
(0.046)\end{array}$ & $\begin{array}{c}0.456^{* *} \\
(0.215)\end{array}$ \\
\hline Bologna06 * size program & $\begin{array}{c}-0.003^{* * *} \\
(0.0005)\end{array}$ & $\begin{array}{c}-0.003^{* * *} \\
(0.0005)\end{array}$ & $\begin{array}{c}-0.003^{* * *} \\
(0.0006)\end{array}$ \\
\hline $\begin{array}{l}\text { Exam: } \\
\text { maths }\end{array}$ & $\begin{array}{c}-0.409^{* * *} \\
(0.060)\end{array}$ & $\begin{array}{c}-0.440^{* * *} \\
(0.063)\end{array}$ & $\begin{array}{c}-0.443^{* * *} \\
(0.062)\end{array}$ \\
\hline physics & $\begin{array}{c}-0.562^{* * *} \\
(0.132)\end{array}$ & $\begin{array}{c}-0.576^{* * *} \\
(0.128)\end{array}$ & $\begin{array}{c}-0.576^{* * *} \\
(0.127)\end{array}$ \\
\hline chemistry & $\begin{array}{l}-0.133 \\
(0.084)\end{array}$ & $\begin{array}{l}-0.124 \\
(0.086)\end{array}$ & $\begin{array}{r}-0.126 \\
(0.088)\end{array}$ \\
\hline biology & $\begin{array}{c}-0.533^{* * *} \\
(0.066)\end{array}$ & $\begin{array}{c}-0.546^{* * *} \\
(0.069)\end{array}$ & $\begin{array}{c}-0.545^{* * *} \\
(0.068)\end{array}$ \\
\hline portuguese & $\begin{array}{l}-0.048 \\
(0.087)\end{array}$ & $\begin{array}{l}-0.105 \\
(0.087)\end{array}$ & $\begin{array}{l}-0.123 \\
(0.088)\end{array}$ \\
\hline $\begin{array}{l}\text { Year: } \\
2004\end{array}$ & $\begin{array}{c}-0.344^{* * *} \\
(0.011)\end{array}$ & $\begin{array}{c}-0.559^{* * *} \\
(0.033)\end{array}$ & $\begin{array}{c}-0.561^{* * *} \\
(0.033)\end{array}$ \\
\hline 2005 & $\begin{array}{c}-0.380^{* * *} \\
(0.017)\end{array}$ & $\begin{array}{c}-0.642^{* * *} \\
(0.037)\end{array}$ & $\begin{array}{c}-0.650^{* * *} \\
(0.038)\end{array}$ \\
\hline 2006 & $\begin{array}{c}-0.340^{* * *} \\
(0.023)\end{array}$ & $\begin{array}{c}-0.409^{* * *} \\
(0.101)\end{array}$ & $\begin{array}{c}-0.513^{* * *} \\
(0.112)\end{array}$ \\
\hline Field of study ${ }^{*}$ year & no & yes & yes \\
\hline $\begin{array}{l}\text { Bologna } 06 * \text { field study: } \\
\text { agriculture }\end{array}$ & & & $\begin{array}{r}-0.413^{*} \\
(0.251)\end{array}$ \\
\hline law, social sciences & & & $\begin{array}{l}-0.292 \\
(0.229)\end{array}$ \\
\hline architecture & & & $\begin{array}{c}-0.474^{* *} \\
(0.228)\end{array}$ \\
\hline natural sciences & & & $\begin{array}{c}-0.426^{*} \\
(0.245)\end{array}$ \\
\hline economics, business & & & $\begin{array}{l}-0.222 \\
(0.239)\end{array}$ \\
\hline sports, arts & & & $\begin{array}{l}0.015 \\
(0.673)\end{array}$ \\
\hline education & & & $\begin{array}{l}0.015 \\
(0.313)\end{array}$ \\
\hline health & & & $\begin{array}{l}-0.382 \\
(0.242)\end{array}$ \\
\hline technologies & & & $\begin{array}{l}-0.202 \\
(0.226)\end{array}$ \\
\hline$\alpha$ & $\begin{array}{c}0.125^{* * *} \\
(0.004)\end{array}$ & $\begin{array}{c}0.115^{* * *} \\
(0.004)\end{array}$ & $\begin{array}{c}0.115^{* * *} \\
(0.003)\end{array}$ \\
\hline $\mathrm{N}$ & 7718 & 7718 & 7718 \\
\hline $\mathrm{N}-\mathrm{g}$ & 1323 & 1323 & 1323 \\
\hline LL & -35972.83 & -35723.63 & -35712.13 \\
\hline
\end{tabular}




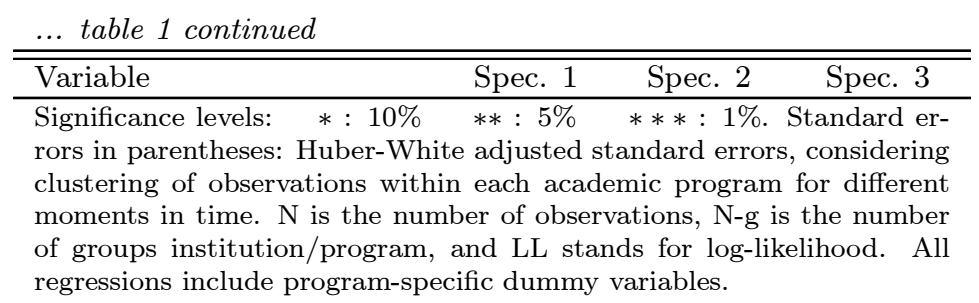

As a preliminary remark, note that this set of results clearly indicates the presence of overdispersion (see the value and significance of the estimated $\alpha$ parameter). This is evidence in favor of the negative binomial specification.

As expected, larger programs (posting more vacancies) are subject to larger demand. Also quite naturally, the second phase gathers a remarkably lower number of applications, since it is a residual phase. The demand for a higher education program is strongly affected by the performance of the candidates in the national admission exams. Requirement of an admission exam on biology, mathematics or physics lowers the demand for the program. Overall demand for university programs declined until 2005 (relative to 2003, the omitted category), recovering in 2006.

Programs that restructured to follow the Bologna principles were subject to an increase in demand, when compared to programs that did not restructure. More precisely, those that restructured were subject to $21 \%(=\exp (0.191))$ higher demand (see specification 1). This effect (slowly) decreases with the dimension of the academic program (note that the magnitude of the coefficient on the size of the program interacted with the Bologna dummy variable is negative, although small in absolute value). The previous results are robust to the introduction (in specification 2) of controls for the different trend over time in demand across scientific fields.

Specification 3 further allows the impact of the adoption of the Bologna principles to be heterogeneous across scientific fields. This is particularly relevant if one keeps in mind that different areas welcomed with different degrees of enthusiasm or skepticism the changes. We find that in the humanities (the omitted category), restructuring of the programs according to the Bologna process was associated with a $58 \%(=\exp (0.456))$ increase in demand (see the coefficient on the overall Bologna dummy); that impact was not significantly different for programs in law, economics and business, sports and arts, education, and technology. The impact was negative for programs in the architecture area, since its estimated coefficient is negative and outweighs the positive 
Bologna effect observed for the base category. ${ }^{13}$

Table 3 in appendix reports comparable results considering as dependent variable the number of applicants who ranked the program as their first choice. Specifications 1 and 2 report findings similar to the previous ones: having restructured to follow Bologna is associated with a $18 \%$ to $22 \%$ (that is, $\exp (0.169)$ and $\exp (0.198)$, respectively) increase in the demand for a program. Specification 3 highlights the positive impact of the Bologna restructuring on the first choice of programs by candidates in the field of education.

We further checked whether the impact of the Bologna process could be different, depending on the intensity of the changes. First of all, we considered whether being a national leader in a certain program implementing the Bologna curricula was associated with some benefit (or penalty) in terms of demand by prospective students (specification 4 in table 2). Secondly, we checked whether restructuring to offer a joint first and second cycle degree (the so-called integrated master) of a longer duration yielded some benefit in terms of demand (specification 5). Then we considered simultaneously those two variables.

The first column in table 2 indeed reveals that being a leader in the implementation of the Bologna curricula led to an increase in demand for a program, above the increase experienced by Bologna implementers in general. This effect holds irrespective of the size of the program.

As to the impact of restructuring to offer an integrated master program, results indicate that there was a positive impact on demand for programs that restructured and kept a long duration, above the impact for Bologna implementers in general; however, this increase in demand took place only for large programs.

Once we check jointly the impact of being a Bologna leader and the impact of having restructured to offer a long integrated master program, the previous results hold: national leaders in the adoption of the Bologna curricula attracted more applicants than Bologna changers in general, and a further increase in demand was directed at large programs that became an integrated master under the Bologna setting.

\footnotetext{
${ }^{13}$ This study area includes not just strictly architecture, but also programs such as design.
} 
Table 2: Demand for academic programs (total number of students choosing the program), including Bologna leader and integrated master variables, negative binomial model

\begin{tabular}{|c|c|c|c|}
\hline Variable & Spec. 4 & Spec. 5 & Spec. 6 \\
\hline Phase 2 & $\begin{array}{c}-0.903^{* * *} \\
(0.024)\end{array}$ & $\begin{array}{c}-0.904^{* * *} \\
(0.024)\end{array}$ & $\begin{array}{c}-0.904^{* * *} \\
(0.024)\end{array}$ \\
\hline Size of program (vacancies) & $\begin{array}{c}0.005^{* * *} \\
(0.0007)\end{array}$ & $\begin{array}{c}0.005^{* * *} \\
(0.0007)\end{array}$ & $\begin{array}{c}0.005^{* * *} \\
(0.0007)\end{array}$ \\
\hline Bologna06 & $\begin{array}{l}0.396^{*} \\
(0.207)\end{array}$ & $\begin{array}{c}0.489^{* *} \\
(0.214)\end{array}$ & $\begin{array}{c}0.431^{* *} \\
(0.206)\end{array}$ \\
\hline Bologna06 $*$ size program & $\begin{array}{c}-0.002^{* * *} \\
(0.0006)\end{array}$ & $\begin{array}{c}-0.004^{* * *} \\
(0.0006)\end{array}$ & $\begin{array}{c}-0.004^{* * *} \\
(0.0007)\end{array}$ \\
\hline Bologna leader & $\begin{array}{l}0.178^{*} \\
(0.092)\end{array}$ & & $\begin{array}{l}0.165^{*} \\
(0.091)\end{array}$ \\
\hline Bologna leader $*$ size program & $\begin{array}{l}-0.001 \\
(0.002)\end{array}$ & & $\begin{array}{c}-0.0006 \\
(0.001)\end{array}$ \\
\hline Integrated master & & $\begin{array}{c}0.036 \\
(0.112)\end{array}$ & $\begin{array}{c}0.052 \\
(0.112)\end{array}$ \\
\hline Integrated master $*$ size program & & $\begin{array}{c}0.004^{* * *} \\
(0.001)\end{array}$ & $\begin{array}{c}0.004^{* * *} \\
(0.001)\end{array}$ \\
\hline $\begin{array}{l}\text { Exam: } \\
\text { maths }\end{array}$ & $\begin{array}{c}-0.445^{* * *} \\
(0.062)\end{array}$ & $\begin{array}{c}-0.448^{* * *} \\
(0.062)\end{array}$ & $\begin{array}{c}-0.451^{* * *} \\
(0.062)\end{array}$ \\
\hline physics & $\begin{array}{c}-0.576^{* * *} \\
(0.127)\end{array}$ & $\begin{array}{c}-0.579^{* * *} \\
(0.128)\end{array}$ & $\begin{array}{c}-0.580^{* * *} \\
(0.128)\end{array}$ \\
\hline chemistry & $\begin{array}{r}-0.127 \\
(0.086)\end{array}$ & $\begin{array}{l}-0.122 \\
(0.088)\end{array}$ & $\begin{array}{l}-0.122 \\
(0.087)\end{array}$ \\
\hline biology & $\begin{array}{c}-0.544^{* * *} \\
(0.068)\end{array}$ & $\begin{array}{c}-0.548^{* * *} \\
(0.068)\end{array}$ & $\begin{array}{c}-0.547^{* * *} \\
(0.068)\end{array}$ \\
\hline portuguese & $\begin{array}{r}-0.111 \\
(0.087)\end{array}$ & $\begin{array}{r}-0.122 \\
(0.088)\end{array}$ & $\begin{array}{r}-0.110 \\
(0.087)\end{array}$ \\
\hline \multicolumn{4}{|l|}{ Year: } \\
\hline 2004 & $\begin{array}{c}-0.561^{* * *} \\
(0.033)\end{array}$ & $\begin{array}{c}-0.561^{* * *} \\
(0.033)\end{array}$ & $\begin{array}{c}-0.561^{* * *} \\
(0.033)\end{array}$ \\
\hline 2005 & $\begin{array}{c}-0.648^{* * *} \\
(0.038)\end{array}$ & $\begin{array}{c}-0.650^{* * *} \\
(0.038)\end{array}$ & $\begin{array}{c}-0.648^{* * *} \\
(0.038)\end{array}$ \\
\hline 2006 & $\begin{array}{c}-0.513^{* * *} \\
(0.112)\end{array}$ & $\begin{array}{c}-0.513^{* * *} \\
(0.112)\end{array}$ & $\begin{array}{c}-0.513^{* * *} \\
(0.112)\end{array}$ \\
\hline Field of study ${ }^{*}$ year & yes & yes & yes \\
\hline $\begin{array}{l}\text { Bologna06 } * \text { field study: } \\
\text { agriculture }\end{array}$ & $\begin{array}{c}-0.418^{*} \\
(0.241)\end{array}$ & $\begin{array}{c}-0.439^{*} \\
(0.251)\end{array}$ & $\begin{array}{c}-0.443^{*} \\
(0.240)\end{array}$ \\
\hline law, social sciences & $\begin{array}{r}-0.298 \\
(0.222)\end{array}$ & $\begin{array}{l}-0.277 \\
(0.228)\end{array}$ & $\begin{array}{r}-0.285 \\
(0.220)\end{array}$ \\
\hline architecture & $\begin{array}{c}-0.510^{* *} \\
(0.226)\end{array}$ & $\begin{array}{c}-0.510^{* *} \\
(0.229)\end{array}$ & $\begin{array}{c}-0.549^{* *} \\
(0.227)\end{array}$ \\
\hline natural sciences & $\begin{array}{c}-0.447^{*} \\
(0.237)\end{array}$ & $\begin{array}{c}-0.415^{*} \\
(0.244)\end{array}$ & $\begin{array}{c}-0.439^{*} \\
(0.236)\end{array}$ \\
\hline economics, business & $\begin{array}{l}-0.215 \\
(0.232)\end{array}$ & $\begin{array}{l}-0.203 \\
(0.238)\end{array}$ & $\begin{array}{l}-0.196 \\
(0.231)\end{array}$ \\
\hline sports, arts & $\begin{array}{l}-0.088 \\
(0.669)\end{array}$ & $\begin{array}{c}0.009 \\
(0.664)\end{array}$ & $\begin{array}{l}-0.092 \\
(0.664)\end{array}$ \\
\hline education & $\begin{array}{l}-0.079 \\
(0.316)\end{array}$ & $\begin{array}{c}0.033 \\
(0.311)\end{array}$ & $\begin{array}{l}-0.068 \\
(0.315)\end{array}$ \\
\hline health & $\begin{array}{l}-0.338 \\
(0.234)\end{array}$ & $\begin{array}{c}-0.436^{*} \\
(0.237)\end{array}$ & $\begin{array}{c}-0.390^{*} \\
(0.229)\end{array}$ \\
\hline
\end{tabular}




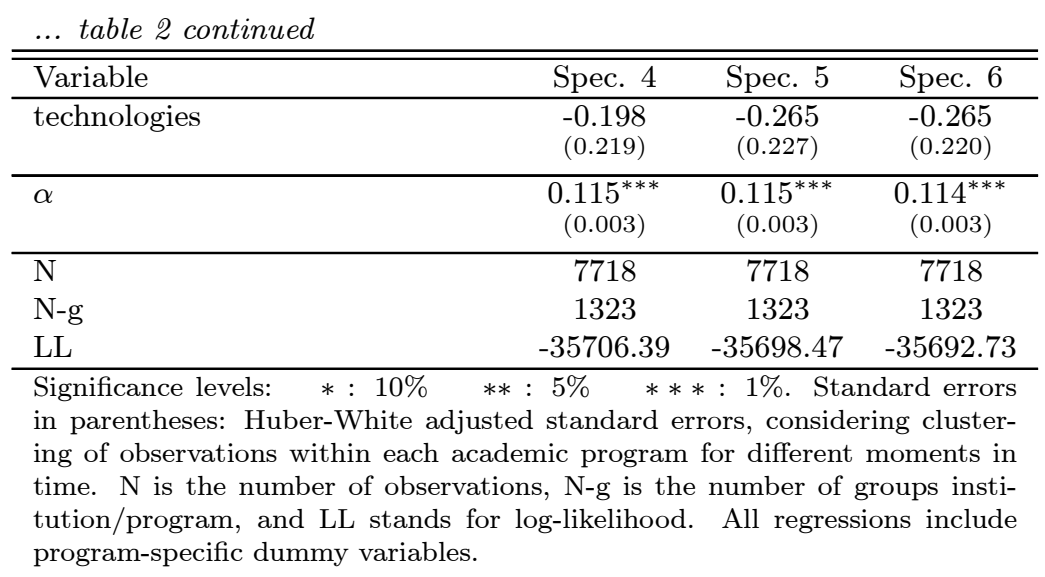

Table 4 in appendix shows results of the same specifications, considering as dependent variable the number of candidates who chose the program as their first option. Results highlight that the impact of the Bologna changes was more pronounced in education; being a leader does not yield a significant impact on the first option listed by candidates, while having restructured to become an integrated master does have a positive impact.

\section{Conclusion}

We have checked the impact on the demand for academic programs resulting from the remarkable changes in the curricula currently taking place under the Bologna process. The relevance of the issue follows from the mix of enthusiasm and criticism that these changes have raised, in countries where the first cycle of higher education used to last for four or five years and is now reduced to three years. Analysis of the issue is feasible in Portugal, since the procedure of application to higher education takes place at the centralized national level and candidates must clearly list their preferences in terms of programs and institutions.

Results clearly indicate that programs that changed their curricula to conform to the Bologna principles were subject to an increase in demand by prospective students. That positive impact on demand was more pronounced if the institution took the lead, being the only institution in the country that restructured the program. We also found that large programs that changed their curriculum to offer an integrated master, thus conforming to the Bologna principles while not reducing the duration of the program, were subject to a further increase in demand. 


\section{References}

Allison, Paul and Waterman (2002). Fixed-effects negative binomial regression models. Sociological Methodology, 32(1): 247-265.

Black, Dan A. And Jeffrey A. Smith (2004). How robust is the evidence on the effects of college quality? Evidence from matching. Journal of Econometrics, 121(1-2): 99-124.

Cameron, A. Colin and Pravin K. Trivedi (1998). Regression Analysis of Count Data. Cambridge: Cambridge University Press.

Gibbons, Robert (1992). A Primer in Game Theory. London: Prentice Hall.

Guimarães, Paulo (2006). The fixed effects negative binomial model revisited. Medical University of South Carolina, mimeo.

Guimarães, Paulo and Richard Lindrooth (2005). Dirichlet-multinomial regression. Medical University of South Carolina, mimeo, available at: http://129.3.20.41/eps/em/papers/0509/0509001.pdf.

Hausman, Jerry, Bronwyn H. Hall and Zvi Griliches (1984). Econometric models for count data with an application to the patents-R\&D relationship. Econometrica, 52(4): 909-938.

LONG, BRIDGet TERrY (2004). How have college decisions changed over time? An application of the conditional logistic choice model. Journal of Econometrics, 121(1-2): 271-296.

MSthe (Ministry of Science, technology and Higher Education) (2006). Reviews of National Policies for Education: Tertiary Education in Portugal. Background Report. Available at: http://www.mctes.pt/docs/ ficheiros/EDU_EC_2006_26.pdf.

Mizrahi, Shlomo And Abraham Mehrez (2002) Managing quality in higher education systems via minimal quality requirements: signaling and control. Economics of Education Review, 21(1): 53-62. 


\section{OeCD (Organization for Economic Co-operation and Development)}

(2006). Reviews of National Policies for Education: Tertiary Education in Portugal. Examiner's Report. Available at: http://www.mctes.pt/docs/ ficheiros/OCDE___Relatorio__124_paginas_.pdf.

Reichert, Sybille And Christian Tauch (2005). Trends IV: European Universities Implementing Bologna. Brussels: European University Association.

Salanié, Bernard (2000). The Economics of Contracts. A Primer. Cambridge: The MIT Press.

van der Ploeg, Frederick And Reinhilde Veugelers (2007). Higher education reform and the renewed Lisbon strategy: role of member states and the European Commission. CESifo Working Paper Series 1901.

\section{Appendix: additional tables}

Table 3: Demand for academic programs (number of students choosing the program as their first choice), negative binomial model

\begin{tabular}{|c|c|c|c|}
\hline Variable & Spec. 1 & Spec. 2 & Spec. 3 \\
\hline Phase 2 & $\begin{array}{c}-0.780^{* * *} \\
(0.024)\end{array}$ & $\begin{array}{c}-0.780^{* * *} \\
(0.024)\end{array}$ & $\begin{array}{c}-0.780^{* * *} \\
(0.024)\end{array}$ \\
\hline Size of program (vacancies) & $\begin{array}{c}0.003^{* * *} \\
(0.0006)\end{array}$ & $\begin{array}{c}0.003^{* * *} \\
(0.0006)\end{array}$ & $\begin{array}{c}0.003^{* * *} \\
(0.0006)\end{array}$ \\
\hline Bologna06 & $\begin{array}{c}0.169^{* * *} \\
(0.044)\end{array}$ & $\begin{array}{c}0.198^{* * *} \\
(0.047)\end{array}$ & $\begin{array}{c}0.227 \\
(0.209)\end{array}$ \\
\hline Bologna06 $*$ size program & $\begin{array}{c}-0.002^{* * *} \\
(0.0005)\end{array}$ & $\begin{array}{c}-0.002^{* * *} \\
(0.0005)\end{array}$ & $\begin{array}{c}-0.002^{* * *} \\
(0.0005)\end{array}$ \\
\hline $\begin{array}{l}\text { Exam: } \\
\text { maths }\end{array}$ & $\begin{array}{c}-0.523^{* * *} \\
(0.074)\end{array}$ & $\begin{array}{c}-0.571^{* * *} \\
(0.075)\end{array}$ & $\begin{array}{c}-0.576^{* * *} \\
(0.076)\end{array}$ \\
\hline physics & $\begin{array}{c}-0.337^{* *} \\
(0.147)\end{array}$ & $\begin{array}{c}-0.386^{* * *} \\
(0.141)\end{array}$ & $\begin{array}{c}-0.387^{* * *} \\
(0.141)\end{array}$ \\
\hline chemistry & $\begin{array}{l}-0.111 \\
(0.120)\end{array}$ & $\begin{array}{l}-0.093 \\
(0.125)\end{array}$ & $\begin{array}{l}-0.097 \\
(0.126)\end{array}$ \\
\hline biology & $\begin{array}{c}-0.635^{* * *} \\
(0.085)\end{array}$ & $\begin{array}{c}-0.635^{* * *} \\
(0.084)\end{array}$ & $\begin{array}{c}-0.634^{* * *} \\
(0.083)\end{array}$ \\
\hline portuguese & $\begin{array}{r}-0.010 \\
(0.089)\end{array}$ & $\begin{array}{l}-0.033 \\
(0.092)\end{array}$ & $\begin{array}{l}-0.057 \\
(0.092)\end{array}$ \\
\hline $\begin{array}{l}\text { Year: } \\
2004\end{array}$ & $\begin{array}{c}-0.309^{* * *} \\
(0.015)\end{array}$ & $\begin{array}{c}-0.506^{* * *} \\
(0.051)\end{array}$ & $\begin{array}{c}-0.506^{* * *} \\
(0.052)\end{array}$ \\
\hline 2005 & $\begin{array}{c}-0.417^{* * *} \\
(0.022)\end{array}$ & $\begin{array}{c}-0.600^{* * *} \\
(0.057)\end{array}$ & $\begin{array}{c}-0.603^{* * *} \\
(0.057)\end{array}$ \\
\hline 2006 & $\begin{array}{c}-0.430^{* * *} \\
(0.027)\end{array}$ & $\begin{array}{c}-0.475^{* * *} \\
(0.107)\end{array}$ & $\begin{array}{c}-0.486^{* * *} \\
(0.124)\end{array}$ \\
\hline Field of study $*$ year & no & yes & yes \\
\hline
\end{tabular}


... table 3 continued

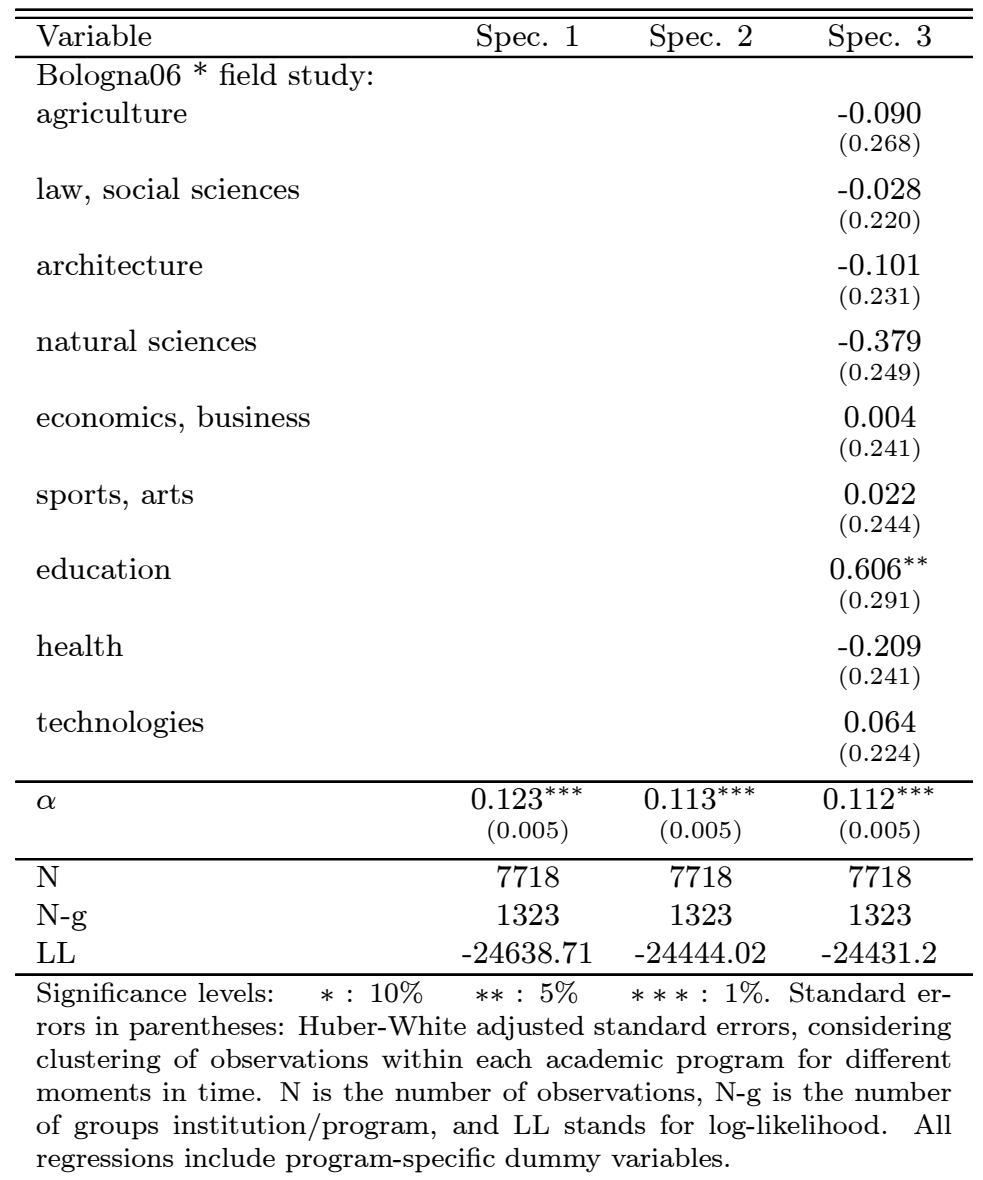

Table 4: Demand for academic programs (number of students choosing the program as their first choice), including Bologna leader and integrated master variables, negative binomial model

\begin{tabular}{|c|c|c|c|}
\hline Variable & Spec. 4 & Spec. 5 & Spec. 6 \\
\hline Phase 2 & $\begin{array}{c}-0.779^{* * *} \\
(0.024)\end{array}$ & $\begin{array}{c}-0.782^{* * *} \\
(0.024)\end{array}$ & $\begin{array}{c}-0.780^{* * *} \\
(0.024)\end{array}$ \\
\hline Size of program (vacancies) & $\begin{array}{c}0.004^{* * *} \\
(0.0006)\end{array}$ & $\begin{array}{c}0.004^{* * *} \\
(0.0006)\end{array}$ & $\begin{array}{c}0.004^{* * *} \\
(0.0006)\end{array}$ \\
\hline Bologna06 & $\begin{array}{c}0.217 \\
(0.205)\end{array}$ & $\begin{array}{c}0.257 \\
(0.208)\end{array}$ & $\begin{array}{c}0.246 \\
(0.204)\end{array}$ \\
\hline Bologna06 $*$ size program & $\begin{array}{c}-0.002^{* * *} \\
(0.0006)\end{array}$ & $\begin{array}{c}-0.003^{* * *} \\
(0.0007)\end{array}$ & $\begin{array}{c}-0.003^{* * *} \\
(0.0008)\end{array}$ \\
\hline Bologna leader & $\begin{array}{c}0.010 \\
(0.087)\end{array}$ & & $\begin{array}{c}0.010 \\
(0.087)\end{array}$ \\
\hline Bologna leader $*$ size program & $\begin{array}{c}0.001 \\
(0.002)\end{array}$ & & $\begin{array}{c}0.002 \\
(0.002)\end{array}$ \\
\hline Integrated master & & $\begin{array}{l}0.212^{*} \\
(0.122)\end{array}$ & $\begin{array}{l}0.214^{*} \\
(0.123)\end{array}$ \\
\hline Integrated master $*$ size program & & $\begin{array}{c}0.002^{* *} \\
(0.001)\end{array}$ & $\begin{array}{c}0.003^{* *} \\
(0.001)\end{array}$ \\
\hline $\begin{array}{l}\text { Exam: } \\
\text { maths }\end{array}$ & $-0.577^{* * *}$ & $-0.586^{* * *}$ & $-0.587^{* * *}$ \\
\hline
\end{tabular}


... table 4 continued

\begin{tabular}{|c|c|c|c|}
\hline Variable & $\begin{array}{c}\text { Spec. } 4 \\
(0.076)\end{array}$ & $\begin{array}{c}\text { Spec. } 5 \\
(0.075)\end{array}$ & $\begin{array}{c}\text { Spec. } 6 \\
(0.075)\end{array}$ \\
\hline physics & $\begin{array}{c}-0.388^{* * *} \\
(0.141)\end{array}$ & $\begin{array}{c}-0.395^{* * *} \\
(0.141)\end{array}$ & $\begin{array}{c}-0.396^{* * *} \\
(0.141)\end{array}$ \\
\hline chemistry & $\begin{array}{l}-0.099 \\
(0.126)\end{array}$ & $\begin{array}{l}-0.089 \\
(0.125)\end{array}$ & $\begin{array}{l}-0.091 \\
(0.126)\end{array}$ \\
\hline biology & $\begin{array}{c}-0.633^{* * *} \\
(0.083)\end{array}$ & $\begin{array}{c}-0.638^{* * *} \\
(0.083)\end{array}$ & $\begin{array}{c}-0.638^{* * *} \\
(0.083)\end{array}$ \\
\hline portuguese & $\begin{array}{l}-0.053 \\
(0.092)\end{array}$ & $\begin{array}{l}-0.058 \\
(0.092)\end{array}$ & $\begin{array}{l}-0.054 \\
(0.092)\end{array}$ \\
\hline \multicolumn{4}{|l|}{ Year: } \\
\hline 2004 & $\begin{array}{c}-0.506^{* * *} \\
(0.052)\end{array}$ & $\begin{array}{c}-0.506^{* * *} \\
(0.052)\end{array}$ & $\begin{array}{c}-0.506^{* * *} \\
(0.052)\end{array}$ \\
\hline 2005 & $\begin{array}{c}-0.602^{* * *} \\
(0.057)\end{array}$ & $\begin{array}{c}-0.603^{* * *} \\
(0.057)\end{array}$ & $\begin{array}{c}-0.603^{* * *} \\
(0.057)\end{array}$ \\
\hline 2006 & $\begin{array}{c}-0.486^{* * *} \\
(0.124)\end{array}$ & $\begin{array}{c}-0.486^{* * *} \\
(0.124)\end{array}$ & $\begin{array}{c}-0.486^{* * *} \\
(0.124)\end{array}$ \\
\hline Field of study ${ }^{*}$ year & yes & yes & yes \\
\hline $\begin{array}{l}\text { Bologna06 } * \text { field stuc } \\
\text { agriculture }\end{array}$ & $\begin{array}{l}-0.088 \\
(0.265)\end{array}$ & $\begin{array}{l}-0.142 \\
(0.272)\end{array}$ & $\begin{array}{l}-0.141 \\
(0.267)\end{array}$ \\
\hline law, social sciences & $\begin{array}{l}-0.038 \\
(0.218)\end{array}$ & $\begin{array}{l}-0.019 \\
(0.219)\end{array}$ & $\begin{array}{l}-0.030 \\
(0.217)\end{array}$ \\
\hline architecture & $\begin{array}{l}-0.112 \\
(0.231)\end{array}$ & $\begin{array}{l}-0.172 \\
(0.236)\end{array}$ & $\begin{array}{l}-0.186 \\
(0.235)\end{array}$ \\
\hline natural sciences & $\begin{array}{l}-0.394 \\
(0.248)\end{array}$ & $\begin{array}{l}-0.372 \\
(0.248)\end{array}$ & $\begin{array}{l}-0.390 \\
(0.246)\end{array}$ \\
\hline economics, business & $\begin{array}{c}0.007 \\
(0.239)\end{array}$ & $\begin{array}{c}0.021 \\
(0.240)\end{array}$ & $\begin{array}{l}0.025 \\
(0.237)\end{array}$ \\
\hline sports, arts & $\begin{array}{l}-0.010 \\
(0.254)\end{array}$ & $\begin{array}{c}0.018 \\
(0.241)\end{array}$ & $\begin{array}{l}-0.019 \\
(0.252)\end{array}$ \\
\hline education & $\begin{array}{l}0.556^{*} \\
(0.303)\end{array}$ & $\begin{array}{c}0.616^{* *} \\
(0.288)\end{array}$ & $\begin{array}{l}0.556^{*} \\
(0.300)\end{array}$ \\
\hline health & $\begin{array}{l}-0.194 \\
(0.237)\end{array}$ & $\begin{array}{l}-0.273 \\
(0.240)\end{array}$ & $\begin{array}{l}-0.256 \\
(0.236)\end{array}$ \\
\hline technologies & $\begin{array}{c}0.063 \\
(0.221)\end{array}$ & $\begin{array}{l}-0.062 \\
(0.227)\end{array}$ & $\begin{array}{l}-0.064 \\
(0.225)\end{array}$ \\
\hline$\alpha$ & $\begin{array}{c}0.112^{* * *} \\
(0.005)\end{array}$ & $\begin{array}{c}0.111^{* * *} \\
(0.005)\end{array}$ & $\begin{array}{c}0.111^{* * *} \\
(0.005)\end{array}$ \\
\hline $\mathrm{N}$ & 7718 & 7718 & 7718 \\
\hline $\mathrm{N}-\mathrm{g}$ & 1323 & 1323 & 1323 \\
\hline LL & -24430.03 & -24416.98 & -24415.28 \\
\hline $\begin{array}{l}\text { Significance levels: } \\
\text { theses: Huber-White ac } \\
\text { vations within each aca } \\
\text { number of observations } \\
\text { LL stands for log-likelil } \\
\text { variables. }\end{array}$ & $\begin{array}{l}\text { \% } \quad * * *: 1 \\
d \text { errors, con } \\
\text { for different } \\
\text { nber of grou } \\
\text { ssions inclu }\end{array}$ & $\begin{array}{l}\text { Standard e } \\
\text { dering clust } \\
\text { moments in } \\
\text { institution } \\
\text { program-s }\end{array}$ & $\begin{array}{l}\text { ors in paren- } \\
\text { ing of obser- } \\
\text { me. } \mathrm{N} \text { is the } \\
\text { rogram, and } \\
\text { cific dummy }\end{array}$ \\
\hline
\end{tabular}


Table 5: Summary statistics by year and phase

\begin{tabular}{|c|c|c|c|c|c|c|c|c|}
\hline \multirow[b]{2}{*}{ Variable } & \multicolumn{2}{|c|}{2003} & \multicolumn{2}{|c|}{2004} & \multicolumn{2}{|c|}{2005} & \multicolumn{2}{|c|}{2006} \\
\hline & Ph1 & Ph2 & Ph1 & $\mathrm{Ph} 2$ & Ph1 & Ph2 & Ph1 & $\mathrm{Ph} 2$ \\
\hline \multirow[t]{2}{*}{ Demand: number of hits } & 196.94 & 64.95 & 195.25 & 38.35 & 178.61 & 56.20 & 194.22 & 69.36 \\
\hline & $(207.70)$ & $(55.73)$ & $(204.13)$ & $(36.56)$ & $(227.91)$ & $(52.30)$ & $(230.33)$ & $(59.93)$ \\
\hline \multirow[t]{2}{*}{ Demand: first option } & 42.56 & 15.76 & 41.91 & 10.14 & 37.68 & 13.07 & 40.92 & 15.64 \\
\hline & $(63.06)$ & $(18.27)$ & $(61.91)$ & $(14.07)$ & $(65.91)$ & $(17.60)$ & $(66.87)$ & $(18.97)$ \\
\hline Bologna06 & & & & & & & 0.43 & 0.43 \\
\hline Bologna leader & & & & & & & 0.17 & 0.17 \\
\hline Integrated master & & & & & & & 0.04 & 0.04 \\
\hline \multirow{2}{*}{ Size of the program (vacancies) } & 45.66 & 14.21 & 44.69 & 12.92 & 44.23 & 16.96 & 46.96 & 17.20 \\
\hline & $(33.19)$ & $(13.40)$ & $(39.27)$ & $(12.24)$ & $(38.99)$ & $(17.46)$ & $(38.76)$ & $(16.69)$ \\
\hline \multicolumn{9}{|c|}{ ) } \\
\hline maths & 0.33 & 0.33 & 0.28 & 0.28 & 0.26 & 0.27 & 0.21 & 0.21 \\
\hline physics & 0.05 & 0.06 & 0.03 & 0.03 & 0.03 & 0.03 & 0.02 & 0.02 \\
\hline chemistry & 0.07 & 0.07 & 0.07 & 0.06 & 0.07 & 0.06 & 0.05 & 0.05 \\
\hline biology & 0.16 & 0.15 & 0.13 & 0.13 & 0.14 & 0.13 & 0.11 & 0.11 \\
\hline portuguese & 0.12 & 0.13 & 0.10 & 0.11 & 0.08 & 0.08 & 0.07 & 0.07 \\
\hline \multicolumn{9}{|l|}{ Field of study: } \\
\hline agriculture & 0.06 & 0.07 & 0.07 & 0.06 & 0.05 & 0.06 & 0.06 & 0.06 \\
\hline architecture & 0.05 & 0.04 & 0.05 & 0.05 & 0.06 & 0.06 & 0.07 & 0.07 \\
\hline natural sciences & 0.07 & 0.07 & 0.07 & 0.08 & 0.07 & 0.07 & 0.08 & 0.08 \\
\hline law, social sciecnes & 0.11 & 0.11 & 0.13 & 0.13 & 0.14 & 0.14 & 0.16 & 0.17 \\
\hline economics, business & 0.10 & 0.10 & 0.10 & 0.11 & 0.10 & 0.11 & 0.11 & 0.11 \\
\hline sports, arts & 0.02 & 0.02 & 0.03 & 0.02 & 0.03 & 0.03 & 0.03 & 0.03 \\
\hline education & 0.13 & 0.14 & 0.11 & 0.11 & 0.09 & 0.09 & 0.07 & 0.08 \\
\hline humanities & 0.11 & 0.11 & 0.11 & 0.11 & 0.10 & 0.10 & 0.08 & 0.08 \\
\hline health & 0.10 & 0.10 & 0.11 & 0.10 & 0.11 & 0.10 & 0.11 & 0.11 \\
\hline technologies & 0.24 & 0.24 & 0.24 & 0.24 & 0.23 & 0.24 & 0.22 & 0.22 \\
\hline Programs & 946 & 903 & 989 & 942 & 1012 & 976 & 985 & 965 \\
\hline
\end{tabular}


Table 6: Proportion of academic programs adopting the Bologna curricula in 2006/07, by institution

\begin{tabular}{lrrlrr}
\hline \hline Universities & $\mathbf{N r}$ & $\%$ & Polytechnics & $\mathbf{N r}$ & $\mathbf{\%}$ \\
\hline ISCTE & 15 & 93.3 & IP Beja & 18 & 55.6 \\
U Açores & 27 & 29.6 & IP Bragança & 41 & 68.3 \\
U Algarve & 50 & 38.0 & IP Castelo Branco & 30 & 53.3 \\
U Aveiro & 50 & 68.0 & IP Coimbra & 42 & 2.4 \\
U Beira Interior & 27 & 59.3 & IP Cávado e Ave & 8 & 25.0 \\
U Coimbra & 51 & 2.0 & IP Guarda & 22 & 50.0 \\
U Évora & 32 & 12.5 & IP Leiria & 41 & 22.0 \\
U Lisboa & 48 & 64.6 & IP Lisboa & 30 & 50.0 \\
U Madeira & 18 & 0.0 & IP Portalegre & 22 & 31.8 \\
U Minho & 43 & 65.1 & IP Porto & 50 & 44.0 \\
U Nova de Lisboa & 34 & 85.3 & IP Santarém & 22 & 63.6 \\
U Porto & 56 & 19.6 & IP Setúbal & 26 & 30.8 \\
U Técnica de Lisboa & 51 & 60.8 & IP Tomar & 20 & 40.0 \\
U Trás-os Montes e Alto Douro & 34 & 23.5 & IP Viana do Castelo & 22 & 36.4 \\
& & & IP Viseu & 35 & 51.4 \\
& & & ESuperiores & 20 & 40.0 \\
\hline Notes Thior
\end{tabular}

Notes: This table considers 985 academic programs, of which 419 have adjusted to the Bologna principles, 185 in the polytechnics and 234 in the universities. Although some universities offer polytechnic-type of studies, these are shown only in the university sector column. ESuperiores include 11 institutions: a nautic school, a hotel management school, and 9 nursing shools. For more details on data descritpion see section 3.1. 